INHALT

W. I. SuIRNow

E. Grumbr \&

H. LÜTZNER

Z. OLEWICZ

K. LEHNERT

W. REMUS

H. SCHEFFLER

M. B. BORODA-

JEWSKAJA \&

N. I. BORODAJEWSKI

F. STAMMBERGER

\section{O. WAGENBRETH}

C. MUEHLBERGER

A. K. WETROW \&

J. I. TSCHEKA WIJ

R. MEINHOLD

L. Eissmani

W. MARTIN

H. ULBRTCH

37. Jahrestagung der Deutschen Mineralogischen Gesellschaft vom 8. bis 12. 9. 1959 in Wetzlar (Lahn)

Feststellung der gesetzmäßigen Verteilung nutzbarer Bodenschätze auf dem Territorium der UdSSR

Zur Leitbankgliederung des Staßfurtsteinsalzes und -kalilagers der Schachtanlagen Volkenroda-Pöthen (Thüringen)

Perspektiven der Erdölführung in der Umgebung von Wieluń

Einige Besonderheiten konventioneller elektrischer Bohrlochmeßkurven in "hartem" Gebirge

Stickstoffausbrüche in den Mansfelder Schichten (Stefan)

Verwachsungsverhältnisse von Pyrit und Keratophyr auf der Schwefelkieslagerstätte Grube „Einheit", Elbingerode (Harz)

Die Rolle der Kleinintrusionen und der Gesteinsgänge bei der Lokalisierung der Erzkörper

Zur Festlegung der Konditionen für mineralische Rohstoffe (Der Standpunkt einiger sowjetischer Autoren)

Instruktion zur Anwendung der ,Klassifikation der Lagerstättenvorräte fester mineralischer Rohstoffe" auf Braunkohlen-Lagerstätten der Deutschen Demokratischen Republik

Zwei Hilfsverfahren zum Zeichnen geologischer Profile

Die Bedeutung der GrundwasserOrganismen für hydrogeologische Erkundungen

Veränderung des Spülungsregimes beim Schrotbohren

15 Jahre polnisches Erdölinstitut

Bericht über die geomorphologischen Exkursionen auf der XXXII. Tagung der Polnischen Geologischen Gesellschaft vom 4. bis 7. 9. 1959 in Zakopane

5. Internationales Symposium der ungarischen Geophysiker vom 8. bis 12.9.1959 in Budapest.

\section{СО ДВРЖА НИЕ}

Отчет о 5-м Международном симпозиуме венгерских геофизиков от 8-12 сентября 1959 г. в г. Будапеште

Отчет о 37-м Годовом заседании Германского Минералогического Общества от 8-12 сентября 1959 г. в г. Ветцлар (गан)

CONTENTS

становление закономерного распределения полезных Советского Союза

О расчленении направляющего горизонта Стасфуртских залежей каменной и калийной рода-Пэтен (Тюрннгия)

ерспективы нефтеносності в окрестности Велуня

Некоторые особенности обычтельных в условиях ,,твердых" пород

Взрывы азота в Мансфельдснгх слоях (стефанский нрус)

кератофиромнапиритовомместорождени в шахте Ейнгайт" в Эльбингероде (Гарц)

Роль малых интрузй п даек

К определению кондиций для минерального сырья (Мнение некоторых советских авторов)

Инструкция по применению „Классифинации запасов расторождении твердых минеральных ископаемых " для месторождений бурового уг-
ля в Германско Демократической Республике

метода рисовке геологических Значение организмов грунтовых вод для гидрогеологичесних поистов при бурении дробью института

Отчет о геоморфологической әкснурсии на 32-м заседанит больского Геологического
Determination of Regular Distribution of Minable Natural Resources on the Territory of the U.S.S.R. Classification by Key Beds of the Staßfurt Rock Salt and Potash Deposit of the VoIkenroda-Pöthen Mine (Thuringia)

Perspectives of PetroleumBearing Strata in the Surroundings of Wielun

Some Particulars Relating to Conventional Electrically Calibrated Borehole Curves in "Hard" Rock Formation

Nitrogen Outbursts in Mansfeld Strata (Stefan Stage)

Intergrowth Conditions of Pyrites and Keratophyre of the Pyrite Deposit "Einheit" of Elbingerode (Harz)

Role of Small Intrusions and Dikes in Ore Body Localization

Determination of Conditions for Mineral Raw Materials (As Seen by Some Soviet Authors)

Instruction Concerning the Application to Brown-Coal Deposits of the German Democratic Republic of "Deposit Reserve Classification of Solid Mineral Raw Materials"

Two Auxiliary Methods of Geological Profile Drawing

The Importance of Groundwater Organisms for $\mathrm{Hy}$ drogeological Exploration

Variation of Rinsing Liquid Regime in Shot-Drilling

15th Anniversary of the Polish Petroleum Institute

Report on the Geomorphological Excursion Organized during the 32nd Meeting of the Polish Geological Society, Zakopane, September $4-71959$

Report on the 5th International Symposium Held by Hungarian Geophysicists, Budapest, September $8-12,1959$

Report on the 37th Annual Meeting of the German Mineralogical Society,

Wetzlar (Lahn), September $8-12,1959$

Lesesteine, Besprechungen und Referate, Nachrichten und Informationen, Kurznachrichten

193

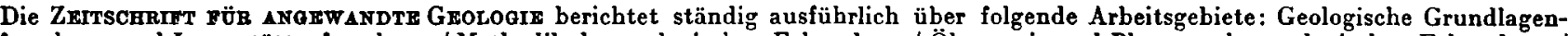
forschung und Lagerstättenforschung / Methodik der geologischen Erkundung / Ökonomie und Planung der geologischen Erkundung / Technik der geologischen Erkundung / Geologie und Lagerstättenkunde im Ausland / Bibliographie, Verordnungen, Richtlinien, Konferenzen, Personalnachrichten

Dem Redaktionskollegium gehören an:

Prof. Dipl.-Berging. BÜHRIG, Nordhausen - Prof. Dr. HECK, Schwerin - Prof. Dr. HOHL, Freiberg/Sa. - Prof. Dr. KAUTZSCH, Berlin - Prof. Dr. LANGE, Berlin -Dr. MEINHOLD, Leipzig - Dr. NOSSKE, Leipzig - Prof. Dr. PIETZSCH, Freiberg - Dr. REH, Jena Prof. Dr. SCHÜLLER, Berlin - Dipl.-Berging.-Geologe STAMMBERGER, Berlin - Prof. Dr. WATZNAUER, Karl-Marx-Stadt Chefredakteur: Prof. Dr. ERICH LANGE, Berlin

Die Znitschrift fÜr angewandte Geologie ist kein Organ einer engen Fachgruppe. Auf ihren Seiten können alle strittigen Fragen der praktischen Geologie behandelt werden. Die Autoren übernebmen für ihre Aufsätze die übliche Verantwortung. 